\title{
Syngeneic transplantation of rat pancreatic islets into the spleen. Light and electron microscopical findings
}

\author{
Frank Wohlrab ${ }^{1}$, Barbara Wilke ${ }^{2}$, Siegfried Schmidt ${ }^{2}$ and Lothar Cossel ${ }^{1}$ \\ ${ }^{1}$ Department of Pathology, Karl-Marx-University Leipzig, Leipzig, and ${ }^{2}$ Central Institute of Diabetes \\ Research 'Gerhardt Katsch', Karlsburg, G.D.R.
}

(Received 2 October 1986; Accepted 24 March 1987)

Key words: Lewis rat; Streptozotocin diabetes; Syngeneic islet transplantation; Spleen; Histochemistry; Ultrastructure

\section{Summary}

An islet transplantation model was established with the two congeneic Lewis rat strains LEW.1W and LEW.1A, which were made diabetic by a single i.p. injection of $50 \mathrm{mg} / \mathrm{kg} \mathrm{b.w}$. streptozotocin. Isolated neonatal islets of the two strains served as a graft. Syngeneic transplantation into the spleen resulted in permanent graft survival and in normoglycemia of streptozotocin diabetic rats of the two strains. 200 days after transplantation functionally intact islets were demonstrable in the spleen by histological, histochemical and electron microscopical investigations. Histochemical findings indicate an activation of interdigitating reticular cells in the white pulp and of macrophages in the red pulp of the spleen as consequences of the islet transplantation. In addition a few electron microscopical findings concerning possible interactions between host plasma cells, lymphocytes and transplanted beta cells of islets are described and discussed.

Correspondence to: Frank Wohlrab, Department of Pathology, Karl-Marx-University Leipzig, 7010 Leipzig, Liebigstr. 26, G.D.R.

Presented in part at the Second European Congress on Cell Biology, July 6-11, 1986, Budapest, Hungary. Dedicated to Professor Dr. Z. Lojda on the occasion of his 60 th birthday. 


\section{Introduction}

This study describes for the first time light (histochemical and immunohistological) and electron microscopical findings in an islet transplantation model, in which donor and recipient came from the congeneic Lewis rat strains LEW.1W and LEW.1A and in which the islet graft was cultured and functionally characterized in vitro before transplantation. This defined rat islet transplantation model allows the morphological investigation.

\section{Materials and Methods}

\section{Animals and induction of diabetes}

The two congeneic rat strains LEW.1W/MaxK (RT1 ${ }^{u}$ ) and LEW.1A/MaxK $\left(\mathrm{RT}^{\mathrm{a}}\right)$ were bred in our breeding colony and kept under constant conditions (12 hr light-dark regime, $22 \pm 2^{\circ} \mathrm{C}, 60 \pm 5 \%$ relative humidity, standard pellet chow and tap water ad libitum).

Femal congeneic LEW rats weighing $150-180 \mathrm{~g}$ were rendered diabetic with a single dose of streptozotocin (Upjohn Co., Kalamazoo, U.S.A.) $(50 \mathrm{mg} / \mathrm{kg}$ body weight, i.p.). All rats remained diabetic without any further treatment for one week. Thereafter they were treated with a daily injection of insulin (2.0 IU) until they served as recipients. Only animals with a nonfasting plasma glucose concentration of 17 $\mathrm{mmol} / 1$ were used for transplantation.

\section{Islet isolation}

Pancreatic islets were isolated using a modification of the collagenase digestion/ Ficoll separation technique [6]. Under sterile conditions the pancreata were rapidly excised from the donor and connecting tissue and fat tissue were removed from the gland. Twenty pancreata were placed in a vial containing $5 \mathrm{ml}$ collagenase solution (Serva, Heidelberg, F.R.G.) $(0.6 \mathrm{mg} / \mathrm{ml})$. After vigorous shaking by hand (over 5 $\mathrm{min}$ ), the partly digested pancreatic tissue was transferred into a second vial containing $5 \mathrm{ml}$ collagenase solution and was shaken by hand for about 5-7 min. The crude undigested pancreatic tissue was then transferred into a third digestion vial with $5 \mathrm{ml}$ collagenase. Both vials were vigorously shaken until the supernatant contained almost only small exocrine particles and free islets. Crude undigested tissue particles were removed, the supernatant containing exocrine cells and islets were separated from the exocrine cells by centrifugation on a Ficoll (Pharmacia, Uppsala,

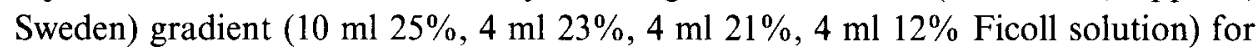
$20 \mathrm{~min}$ at $600 \mathrm{~g}$. Free islets were hand-picked with a finely drawn Pasteur pipette under a dissecting microscope. 


\section{Islet culture}

The isolated islets were washed two times with tissue culture medium 199 from Parker, supplemented with $10 \%$ newborn calf serum (both from Institut für Immunpräparate und Nährmedien, Berlin, G.D.R.), $4.5 \mathrm{mmol} / 1 \mathrm{Mg}^{++}, 20 \mathrm{mmol} / 1 \mathrm{HEPES}$, $50 \mathrm{mg} / \mathrm{l}$ gentamycine and glucose to a final concentration of $10 \mathrm{mmol} / \mathrm{l}$. Batches of $1000-1300$ islets were cultured for 4 or 5 days in a humidified atmosphere of $5 \%$ $\mathrm{CO}_{2}$ in air at $37^{\circ} \mathrm{C}$ in petri dishes containing $3 \mathrm{ml}$ of the medium described above [14]. After $24 \mathrm{~h}$ the culture medium was changed.

\section{Viability test in vitro}

Freshly isolated islets and cultured islets were functionally characterized by incubating 5 islets per tube in $200 \mu \mathrm{l}$ of a supplemented Krebs-Ringer-bicarbonate buffer [9] at $1.5,10$ or $20 \mathrm{mmol} / 1$ glucose in the presence of $370 \mathrm{kBq}{ }^{3} \mathrm{H}$-leucine (spec. radioactivity: $2.164 \mathrm{TBq} / \mathrm{mmol}$; Amersham, UK) for $2 \mathrm{~h}$. Methodological details have been described previously $[9,11]$. The ${ }^{3} \mathrm{H}$-leucine incorporation into (pro)insulin was measured by immunoprecipitation of insulin and proinsulin with a specific antibody according to the method of Jahr et al. [4]. Insulin release and insulin content were determined radioimmunologically [3].

\section{Islet transplantation}

Islets (800-1100) were implanted into the spleen of diabetic recipients by injecting the islets with a disponible scalp vein set. The spleen was exposed via an abdominal incision during hexobarbital anesthesia $(0.1 \mathrm{~g} / \mathrm{kg} \mathrm{b} . \mathrm{w}$. $)$ of the diabetic animals. The recipient rats were treated with insulin in a decreasing dosage $(2.0-0.8 \mathrm{IU} /$ day $)$ for the first three days after transplantation. Plasma glucose levels were determined daily for three weeks and then weekly up to 200 days after transplantation. Blood was taken from the tail vein of the animals at approximately 7 a.m. The rats were considered as successfully transplanted if the plasma glucose concentration was 11 mmol/1 or less. Plasma glucose was measured using the Beckman glucose analyzer (model ERA 2001).

\section{Histochemical and immunohistological investigations}

200 days after islets had been transplanted the spleen was removed under hexobarbital anesthesia, fixed in Bouin's solution for $20 \mathrm{hr}$ at room temperature, dehydrated in graded alcohol solution and embedded in paraffin. Serial sections were stained with hematoxylin/eosin and for insulin reactivity with Victoria blue 4 R [12], pseudoisocyanine chloride [8], aldehyde fuchsin [2] and colloidal iron [5]. Immunofluorescence of insulin was histochemically determined with guinea pig anti-porcine 
insulin antiserum (1:5) and fluorescein-labelled immunoglobulin [1]. Control sections were incubated with fluorescein-labelled immunoglobulin alone. Additionally some other reactions were tested (alcian blue; $\mathrm{pH} \mathrm{1.5,} \mathrm{toluidine} \mathrm{blue,} \mathrm{pH} 4.5$; methylene blue; PAS-reaction) in connection with the characterization of noninsulin containing splenic cells, which are reactive with victoria blue $4 \mathrm{R}$.

\section{Electron microscopical investigations}

Splenic tissue was separated within $30-90 \mathrm{~s}$ of removal into $1 \mathrm{~mm}^{3}$ pieces and subsequently, immersed in ice-cooled glutaraldehyde ( $\mathrm{pH}$ 7.2) for $2 \mathrm{hr}$. After washing in $0.2 \mathrm{~mol} / \mathrm{l}$ saccharose solution the pieces were postfixed for $2 \mathrm{hr}$ in $1 \%$ isotonic $\mathrm{OsO}_{4}$ solution ( $\mathrm{pH}$ 7.2). They were hydrated in Tyrode's solution and dehydrated in an ascending acetone series, with adding of $0.5 \%$ phosphotungstic acid and $0.5 \%$ uranyl acetate at the $70 \%$ acetone stage. Embedding in Mikropal with polymerization at $60^{\circ} \mathrm{C}$. Ultrathin sections of transplanted islets and from the borderline between the islets and splenic tissue were prepared with the aid of semithin sections stained with Giemsa's method, using an $\mathrm{OmU}_{2}$ ultramicrotome (Reichert Co., Vienna, Austria). Sections were post-contrasted with lead nitrate and sodium citrate [7] and examined in a SEM 3-2 type $100 \mathrm{kv}$ electron microscope (FSE-works, Berlin-Oberschöneweide, G.D.R.).

\section{Results}

In vitro function of islets

Freshly isolated neonatal islets of the two congeneic rat strains LEW.1W and LEW.1A did not differ in their beta cell specific functions, which were characterized by measuring the ${ }^{3} \mathrm{H}$-leucine incorporation into (pro)insulin, insulin release and insulin content. The glucose-stimulated ${ }^{3} \mathrm{H}$-leucine incorporation into (pro)insulin showed a nearly seven fold and the glucose-stimulated insulin release an almost twelve fold increase, when the glucose concentration was enhanced from 1.5 to 20 $\mathrm{mmol} / 1$.

Neonatal pancreatic islets cultured for 4 days in tissue culture medium 199 at a glucose conncentration of $10 \mathrm{mmol} / 1$ in the presence of $5.3 \mathrm{mmol} / 1 \mathrm{Mg}^{++}$accumulated insulin during the culture period up to $130 \%$ in comparison to the insulin content of freshly isolated islets.

As a result of culture, the islets showed an increased sensitivity to glucose demonstrated by higher absolute rates of ${ }^{3} \mathrm{H}$-leucine incorporation and insulin release at 10 $\mathrm{mmol} / \mathrm{l}$ glucose.

The only difference between the beta cell functions of neonatal islets of LEW.1W and LEW.1A rats was observed in the glucose-stimulated ${ }^{3} \mathrm{H}$-leucine incorporation 


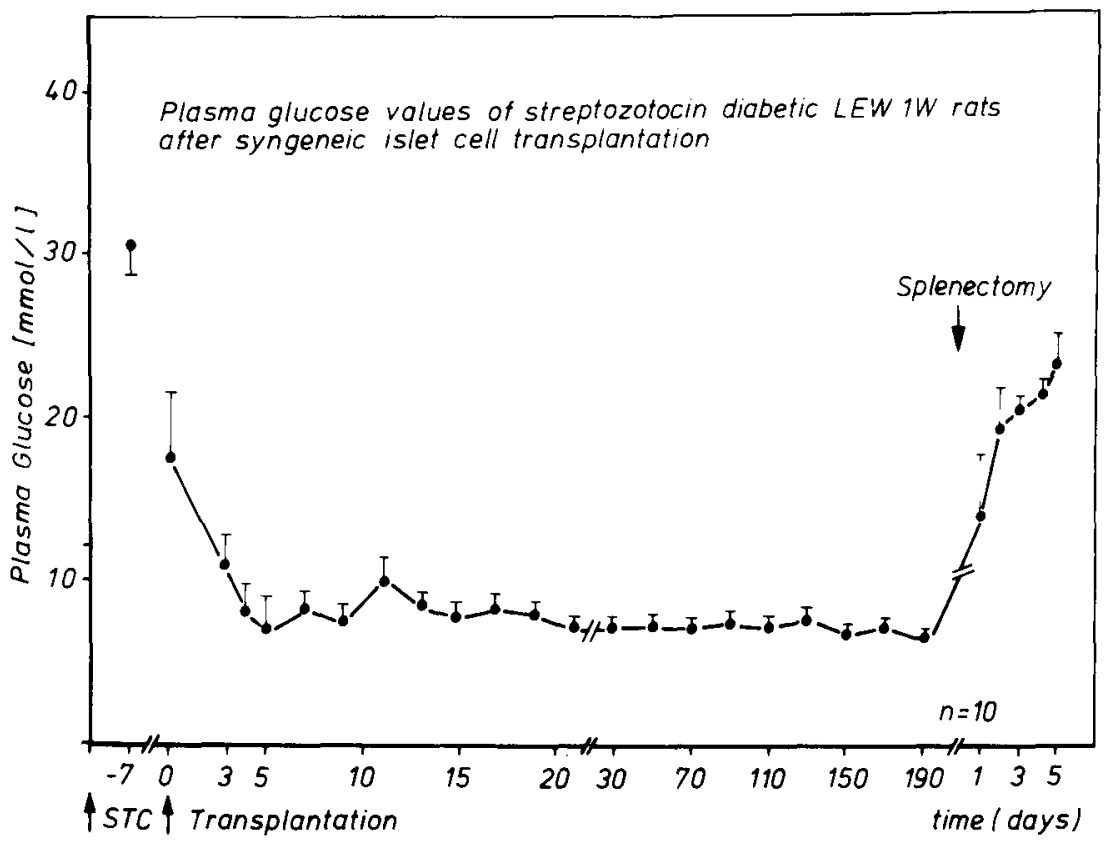

Fig. 1. Plasma glucose values of streptozotocin diabetic LEW.1W rats after syngeneic islet transplantation.

into (pro)insulin and insulin release. At the glucose concentration of $20 \mathrm{mmol} / \mathrm{I}$ ${ }^{3} \mathrm{H}$-leucine incorporation into (pro)insulin was higher and the insulin release was lower in islets of LEW.1A rats after culture compared to LEW. $1 \mathrm{~W}$ islets.

\section{Transplantation model}

The transplantation of $800-1100$ isolated islets from LEW.1A rats and LEW.1W rats resulted in a normalizing of plasma glucose levels within 1-8 days in the syngeneic system (Fig. 1). Allogeneic islet transplantation across the strong histocompatibility barrier $\left(\mathrm{RTl}^{\mathrm{u}} \leftrightharpoons \mathrm{RTl}^{\mathrm{a}}\right.$ ) did not result in a normalizing of hypoglycemia.

Light microscopically, a nonaltered border was observed between transplanted islet tissue (Fig. 2A, below) and splenic tissue (Fig. 2A, top). In some cases around the implanted islets few lymphocytic cells were observed in close contact with the implanted islet cells (Fig. 2B). The demonstration of insulin in beta cells by the indirect immunofluorescence technique and the histochemical reactivity with the basic dye victoria blue $4 \mathrm{R}$ showed identical results (Figs. 2C, D). Individual cells, however, are also reactive in orthologic structures of the spleen (red pulp, macrophages; white pulp, nonlymphoid cells at the inner border of the marginal zone and in the periarteriolar lymphocytic sheaths (marginal 'metallophil' macrophages, interdigitating reticular cells)) only following preoxidation of sections and staining by victoria 

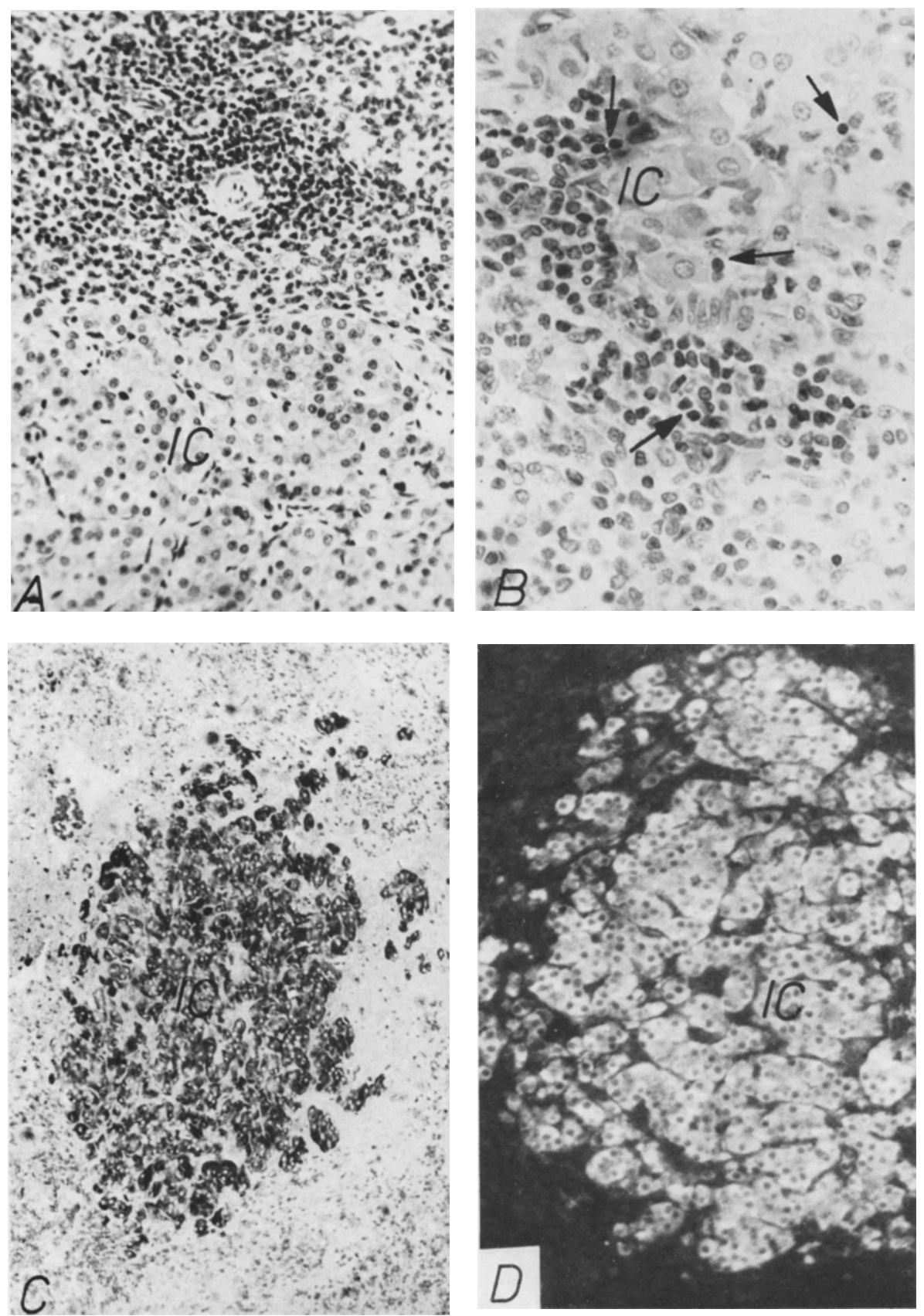

Fig. 2. Section from the transplantation site with intact islet cell regions. (A) Histologically unchanged interface of transplanted islet cells (below) and splenic tissue with folliculary artery (top). Hematoxylineosin. $\times 210$. (B) Lymphocytes (arrows) at the periphery of transplanted islet tissue. Hematoxylin-eosin. $\times 450$. (C) Insulin staining by victoriablue $4 \mathrm{R}$. Abundant insulin containing beta cells are to be seen. $\times 100$. (D) Indirect immunofluorescence with guinea pig anti-insulin serum. The islet graft shows a high fluorescence of insulin containing beta cells. $\times 200$. 

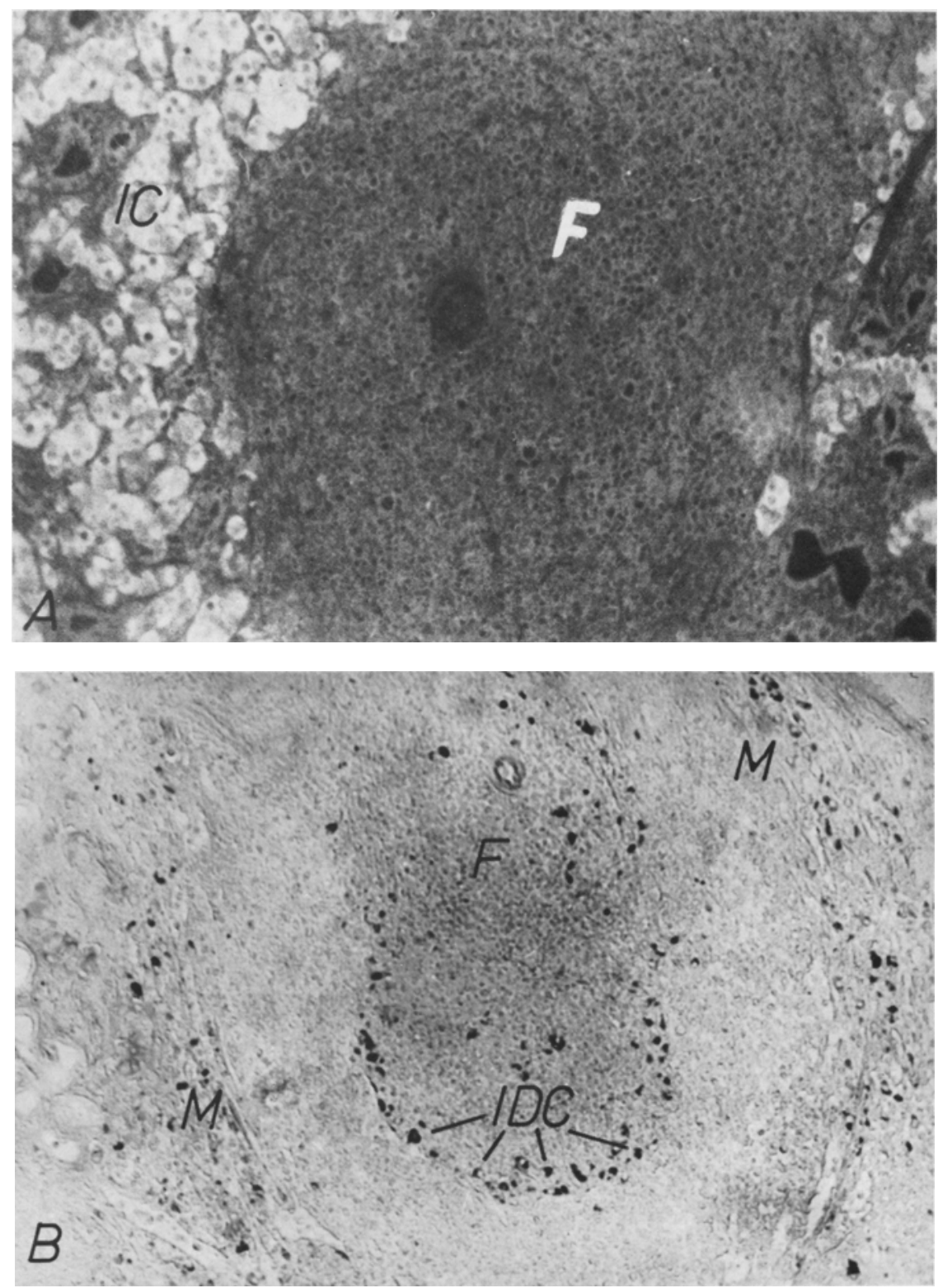

Fig. 3. (A) The islet graft (left and right) show a high fluorescence of insulin containing beta cells (IC). Perifollicular no reactive cells are seen. $F=$ follicle. $\times 145$. (B) Perifollicular reactive cells (IDC) (interdigitating reticular cells; macrophages) are stained by victoriablue $4 \mathrm{R}$ after preoxidation of sections. Some macrophages $(M)$ in the red pulp also reacted. $\times 145$. 
TABLE I

SPLEEN OF FEMALE DIABETIC LEW.IW RATS AFTER SYNGENEIC ISLET TRANSPLANTATION. HISTOCHEMICAL INVESTIGATIONS

\begin{tabular}{|c|c|c|c|c|}
\hline \multirow[t]{3}{*}{ Staining reaction } & \multicolumn{2}{|c|}{$\begin{array}{l}\text { Transplanted islets } \\
\text { beta cells }\end{array}$} & \multicolumn{2}{|c|}{$\begin{array}{l}\text { Non-lymphoid cells of } \\
\text { white and red pulp }\end{array}$} \\
\hline & Without & With & Without & With \\
\hline & \multicolumn{2}{|c|}{ preoxidation } & \multicolumn{2}{|c|}{ preoxidation } \\
\hline Victoria blue $4 \mathrm{R}$ & - & + & - & + \\
\hline Aldehyde fuchsin & - & + & - & + \\
\hline Pseudoisocyanin & - & + & - & + \\
\hline Colloidal iron & $(+)$ & + & $(+)$ & + \\
\hline $\begin{array}{l}\text { Insulin staining by } \\
\text { immunofluorescence }\end{array}$ & + & & - & \\
\hline Alcian blue, $\mathrm{pH} 1,5$ & - & & $(+)$ & \\
\hline Toluidine blue, $\mathrm{pH} 4,5$ & $(+)$ & & $(+)$ & \\
\hline PAS reactivity & - & & $(+)$ & \\
\hline Methylene blue & - & & - & \\
\hline
\end{tabular}

blue, but not by immunohistochemical insulin demonstration (Figs. 3A, B). The same cells reacted in the white pulp of spleen in control rats, but with considerably less quantity and intensity. The staining properties of cells obtained by histochemical reactions are compiled in Tables I and II.

TABLE II

STAINING PROPERTIES OF CELLS BY VICTORIA BLUE IN THE SPLEEN OF FEMALE DIABETIC LEW-1W RATS AFTER SYNGENEIC ISLET TRANSPLANTATION

\begin{tabular}{|c|c|c|c|}
\hline & $\begin{array}{l}\text { Pretreatm } \\
\text { Without } \\
\text { preox }\end{array}$ & $\begin{array}{l}\text { section } \\
\text { With }\end{array}$ & Reacting substance \\
\hline Transplanted beta cells & - & + & Insulin \\
\hline $\begin{array}{l}\text { Interdigitating reticular cells } \\
\text { (White pulp) }\end{array}$ & - & + & $\begin{array}{l}\text { Non-known (Electron micro- } \\
\text { scopically: A high synthetic and } \\
\text { secretory capacity of glycopro- } \\
\text { teins) }\end{array}$ \\
\hline $\begin{array}{l}\text { Activated macrophages } \\
\text { (red and white pulp) }\end{array}$ & - & + & $\begin{array}{l}\text { Phagosomal inclusions of insulin } \\
\text { beta granules form attacked beta } \\
\text { cells (?) }\end{array}$ \\
\hline Mast cells & + & & Heparin \\
\hline
\end{tabular}




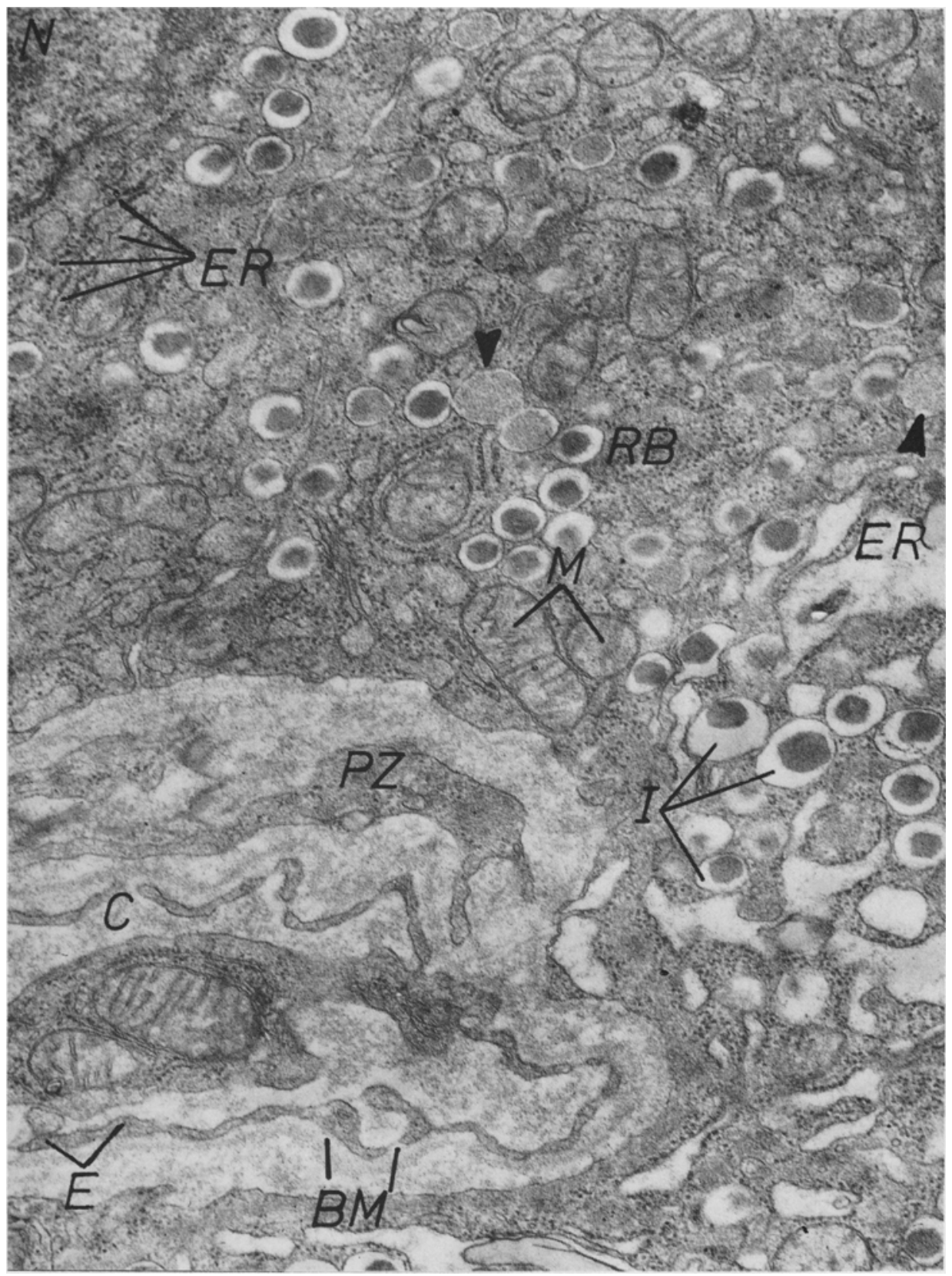

Fig. 4. Well preserved beta cell in an islet of Langerhans 200 days after syngeneic islet transplantation into the spleen (cf. Figs. 2A-D). I = numerous mature insulin granules with light halo. The arrow heads point at immature insulin granules. $\mathrm{ER}=$ rough endoplasmic reticulum with partly dilated cisternae. $\mathrm{RB}$ = ribosomes in the cytoplasmic ground substance. $\mathrm{M}=$ mitochondria. $\mathrm{N}=$ nucleus. $\mathrm{C}=$ islet capillary with endothelial lining $(\mathrm{E})$ and basement membrane $(\mathrm{BM})$. $\mathrm{PZ}=$ parts of a pericyte. $\times 24400$. 


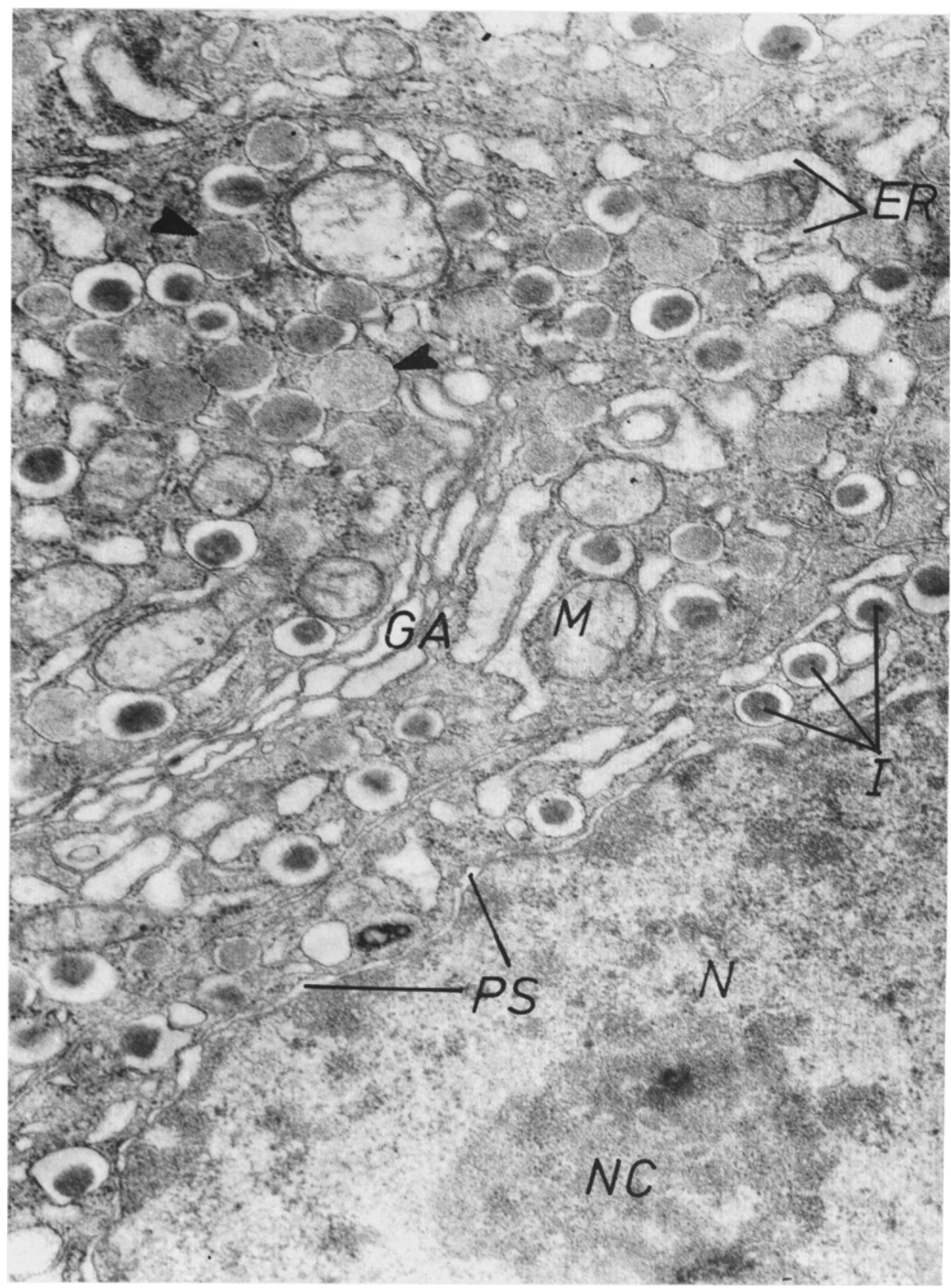

Fig. 5. Well preserved beta cell in an islet of Langerhans 200 days after syngeneic islet transplantation into the spleen. I = numerous mature insulin granules with light halo. The arrow heads point at immature insulin granules. $\mathrm{ER}=$ rough endoplasmic reticulum. $\mathrm{GA}=$ Golgi complex. $\mathrm{M}=$ mitochondria. $\mathrm{N}=$ nucleus. $\mathrm{NC}=$ nucleolus. $\mathrm{PS}=$ perinuclear space. $\times 24800$. 


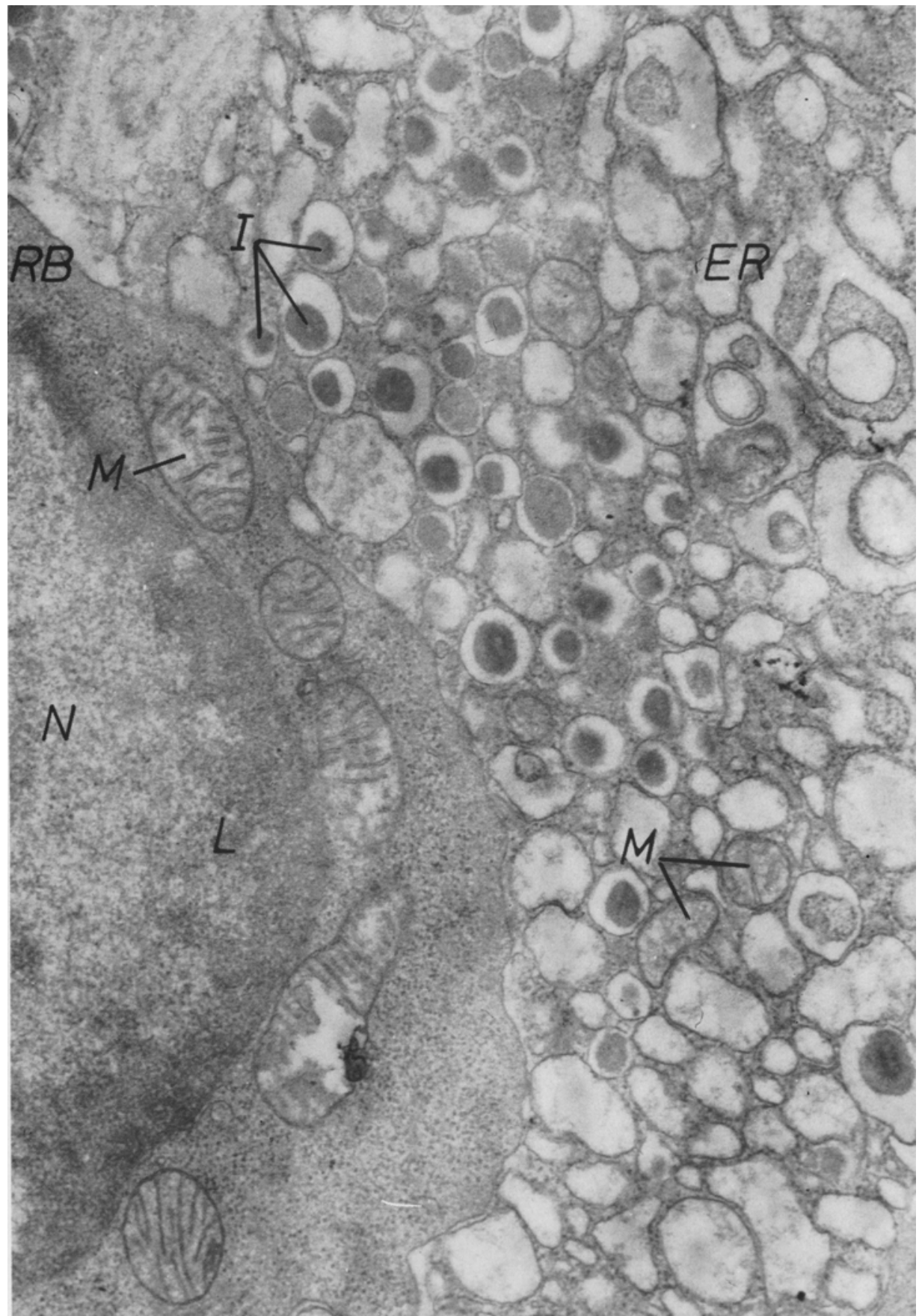

Fig. 6. Infiltrating lymphocyte (L) into the cytoplasm of a beta cell in the periphery of a Langerhans'islet 200 days after syngeneic islet transplantation into the spleen (cf. Fig. 2B). External beta cell membrane cannot be detected at the contact site between lymphocyte and cytoplasm of the beta cell. I = insulin granules. $\mathrm{ER}=$ endoplasmic reticulum. $\mathrm{M}=$ mitochondria. $\mathrm{RB}=$ ribosomes. $\mathrm{N}=$ nucleus. $\times 24800$. 


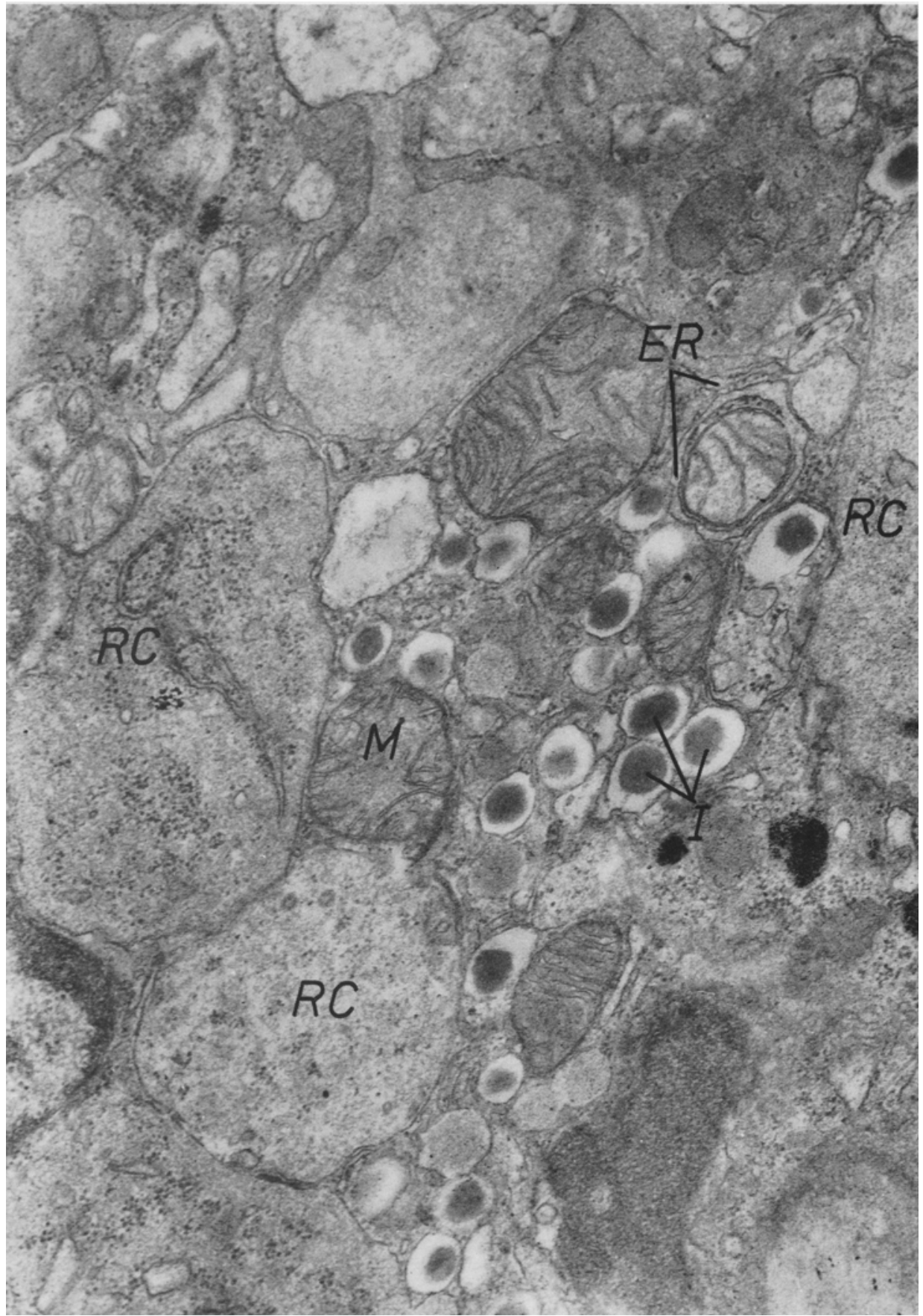

Fig. 7. Cytoplasmic components of beta cells with insulin granules (I), endoplasmic reticulum (ER), mitochondria (M) and ground substance (dissolved cytoplasm of beta cells) in splenic tissue between processes of reticular cells (RC). 200 days after syngeneic islet transplantation into the spleen of a female diabetic LEW. $1 W$ rat. $\times 25600$. 
By electron microscopical investigation well preserved beta cells with immature and mature insulin granules in implanted islets were observed (Figs. 4 and 5). Corresponding to the light microscopical findings (Fig. 2B) lymphocytes and plasma cells in close contact with beta cells were seen. In these regions there are rarely infiltrating lymphocytes within the cytoplasm of beta cells. At the contact site between lymphocytes and beta cell plasma the external beta cell membrane could not be detected (Fig. 6). Between lymphocytes and processes of splenic reticular cells cytoplasmic components of destroyed beta cells were found (Fig. 7).

\section{Discussion}

Culture of pancreatic islets in tissue culture medium 199 from Parker at $10 \mathrm{mmol} / \mathrm{l}$ glucose and $5.3 \mathrm{mmol} / \mathrm{Mg}^{++}$, which was found to be favorable for the maintenance of islet functions to neonatal and adult Wistar rat islets $[13,14]$ also proved to be suitable for neonatal Lewis rat islets in a large-scale culture of about 1000 islets per disk.

The syngeneic transplantation (LEW.1W $\rightarrow$ LEW.1W or LEW.1A $\rightarrow$ LEW.1A) into the spleen resulted in permanent graft survival and in normoglycemia of streptozotocin diabetic rats of the two strains (Fig. 1). In concordance with these functional results 200 days after transplantation the mass of islet cells in the spleen was demonstrable to be morphologically intact by histological, histochemical and electron microscopical investigation. The histochemical findings indicate an activation of red pulp macrophages and of phagocytic resp. secretoric active non-lymphoid cells in the white pulp as a consequence of the islet transplantation. There is no definitive interpretation of our findings in relation to the close contact between lymphocytes, plasma cells and transplanted beta cells and the infiltration of beta cells by lymphocytes (emperiopolesis). The latter findings could be the expression of a mild rejection reaction of host lymphocytes against the transplanted beta cells in the syngeneic system too. Schwizer et al. [10] have observed the destruction of cultured mouse islet cells (CBA/J mice) by syngeneic splenic macrophages in vitro. These authors suggest the possibility that similar destructive interactions between macrophages and glycemiastressed beta cells occur in vivo. The observed remains of dissolved beta cells between splenic reticular cells could derive from such cytolytic reactions or could be indications for a persistent dissolution of few beta cells ('physiological' molting?).

\section{Acknowledgements}

This study is part of the research project HFR 22 (Diabetes mellitus) of the Ministry of Health of the German Democratic Republic. 


\section{References}

1 Coons, A.H., Leduc, E.H. and Conolly, M., Studies on antibody production. I. A method for the histochemical demonstration of specific antibody and its application to a study of hyperimmune rabbit, J. Exp. Med., 1955; 102: 49-63.

2 Gomori, G., Aldehyde fuchsin: A new stain for elastic tissue, Am. J. Clin. Path., 1950; 20: 665-666.

3 Gottschling, H.-D., Ziegler, M., Wilke, W. and Michael, R., Radioimmunoassay von Plasmainsulin. Methodenkritische Untersuchungen. Radiobiol. Radiother. (Berl.), 1974; 15: 85-89.

4 Jahr, H., Schröder, D., Ziegler, B., Ziegler, M. and Zühlke, H., Transcriptional and translational control of glucose-stimulated (pro)insulin biosynthesis. Eur. J. Biochem., 1980; 110: 499-505.

5 Klessen, C., Zur Darstellung der B-Zellen des Inselsystems mit der Eisenbindungsreaktion, Histochemistry, $1975 ; 45: 203-212$.

6 Lernmark, Å., Nielsen, D.A., Nielsen, O. and Larsen, J.K., Light scattering analysis of rat and mouse islet cells in the fluorescence-activated cell sorter, Uppsala Med. Sci., 1981; 86: 119-124.

7 Reynolds, E.S., The use of lead citrate at high $\mathrm{pH}$ as an electronopaque stain in electron microscopy. J. Cell Biol., 1963; 17: 208-212.

8 Schiebler, T.H. and Schiessler, S., Über den Nachweis von Insulin mit den metachromatisch reagierenden pseudoisocyaninen, Histochemie, 1959; 1: 445-465.

9 Schmidt, S., Wilke, B. and Klöting, I., Photochemical (PUVA) treatment of isolated rat islets, Biomed. Biochim. Acta, 1984; 43: 703-710.

10 Schwizer, R.W., Leiter, E.H. and Evans, R., Macrophage-mediated cytotoxicity against cultured pancreatic islet cells. Int. Symposium 'Immunology in Diabetes '84'. Rome/Italy, March 15-17, 1984. Abstract vol., p. 104.

11 Wilke, B., Ziegler, B., Schmidt, S., Woltanski, P. and Zühlke, H., The influence of cultivation on (pro)insulin biosynthesis and secretion of isolated pancreatic islets of C57BL-mice, long-term treated with glibenclamide in vivo, Endokrinologie, 1980; 76: 357-364.

12 Wohlrab, F., Hahn von Dorsche, H., Krautschick, I. and Schmidt, S., On the specificity of the insulin staining by Victoria blue $4 \mathrm{R}$, Histochem. J., 1985; 17: 515-518.

13 Ziegler, B., Einsatzmöglichkeiten der kultivierten Langerhans'schen Insel in der experimentellen Diabetesforschung. Ergebn. exp. Med., 1984; 44: 91-103.

14 Ziegler, B., Kohnert, K.-D., Noack, S. and Hahn, H.-J., Effects of 3-isobutyl-1-methylxanthine on secretory response, cAMP accumulation and DNA synthesis of islets from postnatal and adult Wistar rats, Acta Biol. Med. Germ., 1982; 41: 1171-1177. 